\title{
Spiritualita a kultura
}

\author{
Kamila Němečková \\ Katedra teorie kultury Filosofické fakulty Univerzity Karlovy v Praze, Celetná 20, 11000 Praha 1
}

Do redakce doručeno 5 května 2014; k publikaci přijato 11. června 2014

\section{SPIRITUALITY AND CULTURE}

ABSTRACT We are slowly beginning to realize that the global crisis, has manifested itself on many levels, reflecting the emotional, moral and spiritual condition of contemporary humanity, and is related to distorted perceptions of attitudes and values of modern civilization. The new paradigm, which is opening due to new discoveries and research in science and society, brings a fundamental change towards a holistic and an ecological perspective. Discoveries in quantum physics, systems thinking and research in special fields, have set the foundations for a new perception of reality. The world is viewed as a network of relationships and it seems that discoveries and research has led to the realization that the universe is one interconnected whole, in which we all participate. Spirituality, which was discarded by the Cartesian-Newtonian world view is experiencing a renaissance. Spirituality as an important, innate dimension of life, which is part of a meaningful personal experience, and is found to be a part of the process of cultural evolution. Spiritual process, in terms of evolution to higher states of consciousness, is our own innermost potential. We live in a mono phase society, in which the waking state of consciousness, is regarded as the only acceptable and normal, it is the only section of knowledge suitable for the reproduction of information about the world. Through anthropological research, we know that most human communities considered poly phased consciousness crucial to deeper knowledge. In the new paradigm spirituality occupies a significant place, but a uniformed approach to study the concept of spirituality is lacking. The subject of spirituality and culture attempts to outline a coherent theory of a comprehensive study of spirituality in the future culturological concept in the context of western Christian education and in relation to current scientific discoveries. Addressing the global crisis is in linking the environmental, horizontal plane with the vertical transcendental plane. The horizontal plane stresses pro-environmental cultural strategy and highlights the close connection of philosophy, science and politics and the vertical plane points to the existence of levels and degrees of consciousness and in the context of all mankind, appreciates the inner transformation in each of us. This personal internal transformation indirectly affects cultural evolution.

KEY WORDS Spirituality; global crisis; quantum physics; systems thinking; altered states of consciousness

\begin{abstract}
ABSTRAKT Pomalu si začínáme uvědomovat, že globální krize, která se projevuje na mnoha úrovních, odráží emoční, morální a spirituální stav soudobého lidstva a souvisí s pokřiveným vnímáním postojů a hodnot, jež zastává moderní civilizace. Nové paradigma, které se ve vědě i ve společnosti otevírá, přináší základní změnu směrem k holistickému a ekologickému úhlu pohledu. Široký základ nového vnímání reality položily objevy v kvantové fyzice, systémové myšlení a výzkumy ve speciálních oborech. Svět je nahližen jako sít relací a zdá se, že výzkum vede k pochopení, že celý vesmír, je jedním vzájemně propojeným celkem, na kterém všichni účastně participujeme. Spiritualita, která byla z karteziánsko-newtonovského pohledu na svět vyřazena, zažívá renesanci. Spiritualita jako důležitá, vrozená dimenze života, jejíž nepominutelnou částí je osobní prožitek, je posuzována jako součást procesu kulturní evoluce. Spirituální proces, ve smyslu evoluce vyšších etap vědomí, představuje naše vlastní nejvnitřnější potenciály. Žijeme v monofázové společnosti, ve které je bdělý stav vědomí pokládán za jediný přijatelný a normální a je i jedinou fází vědomí vhodnou pro rozmnožování informací o světě. $Z$ antropologických výzkumů ale víme, že většina lidských společenství považovala za klíčové hluboké poznání přicházející skrze polyfázové vědomí. V novém paradigmatu zaujímá spiritualita významné místo, ale jednotná koncepce pojetí studia spirituality chybí. Předmět studia „Spiritualita a kultura“ se pokouší nastínit koherentní teorii komplexního studia spirituality $\mathrm{v}$ rámci kulturologické koncepce v kontextu západokřestanské vzdělanosti a v návaznosti na současné vědecké objevy. Řešení globální krizové situace se nachází v propojení ekologické, horizontální roviny s rovinou vertikální, transcendentní. Rovina horizontální klade důraz na propřírodní kulturní strategii a zdůrazňuje těsné propojení filosofie, vědy a politiky, vertikální rovina upozorňuje na existenci vývojových stupňủ vědomí a v kontextu celého lidstva oceňuje vnitřní transformace každého $\mathrm{z}$ nás. Tato osobní vnitřní transformace nepř́mo ovlivňuje kulturní evoluci.
\end{abstract}


„Části naší společnosti nejsou jen rozvrácené, ale choré, abych byl upřimný. Když vidíme dvanáctileté, třináctileté děti rabovat, je jasné, že něco v naší společnosti je strašně špatně. V částech společnosti jasně chybí smysl pro odpovědnost. Lidem je dovoleno, aby si mysleli, že jim svět něco dluži a jejich chování nemá žádné důsledky."

Britský premiér David Cameron po nepokojích v Londýně 2011

Chorá je nejen naše společnost, těžce postižený je také náš vnitřní svět a nemocná je i planeta Země. Pro naši informační společnost je typické, že jsme v běžných médiích zahlceni typem informací, které většinou pouze popisují situaci. Víme, kde jsou politické nepokoje, kde došlo k prrírodním katastrofám a kolik lidí zahynulo. Víme, že znečištění naší planety dosáhlo nebývalého stupně a že děti zabíjejí své sourozence. David Cameron je jedním z mála, kdo alespoň vystoupí s podobně tvrdým a zobecňujícím výrokem. Nicméně to, že je „něco strašně špatně můžeme následně odečíst i ze skutečnosti, že si Cameron ve svém vystoupení nepoložil otázky: „Proč si lidé myslí, že jejich chování nemá žádné důsledky?“ A „Proč mají pocit, že jim svět něco dluží?“ Pokud se v rámci jiných článků setkáme s otázkami, kam se lidstvo ubírá, naznačené odpovědi často zůstávají na povrchu a analýzy jdou málokdy hlouběji. Bolestně nám chybí obecné povědomí o skutečných příčinách.

Proč jsme se tedy jako lidstvo dostali do slepé ulice? Kde se stala v našem vývoji chyba? Proč je devastace hodnotových systémů lidí a prrírodního prostředí $\mathrm{v}$ tak pokročilém stadiu? Proč je náš veřejný prostor vyprázdněný od hlubších obsahů? Věda, a to především filosofie, která v moderním světě převzala otěže vedoucí autority ve společnosti, zaspala. „Již nejméně pưl století nám chybí srozumitelné ontologické a hodnotové minimum pro život v ekologicky ohrožené kultuře. Také proto je dospělá populace dnešní informační společnosti vzdělanostně zanedbaná, politicky pasivní a hodnotově zmatená" (Šmajs 2008, 10). Jsme svědky nedozírných změn ve všech oblastech života. Žijeme v době celosvětové krize, krize ekonomické, politické, kulturní a společenské a poprvé v naší historii i krize ekologické. Záchrana života na naši planetě je největší globální výzvou, jaké lidstvo dosud čelilo: neobejde se bez velkých změn ve společnosti a transformace lidské osobnosti" (Metzner $2011,11)$. Nezbývá nám, než najít kořeny globální krize a najít a vyvinout účinné prostředky jejího řešení. Přestože se zatím vlády a jiné instituce soustředují spíše na vojenská, politická, administrativní, právní, ekonomická nebo mělce ekologická východiska, stále častěji se ozývá, že současné krizové jevy jsou symptomem jedné krize a tou je především krize vnímání. "Začínáme chápat, že za destrukci životního prostředi" a pokřivení našeho niterného světa „může lidské jednání, které vychází ze zpưsobu našeho myšlení a chápání světa - ze zkresleného vnímání postoju a hodnot, jež zastává moderní civilizace" (Metzner 2011, 104). Zastaralý světový názor už nestačí k pochopení současné reality a ještě méně je vhodný pro řešení globálních problémů. Vlády a další instituce se sice snaží řešit krizi, ale řeší ji stejnými strategiemi a postoji, které ji vyvolaly. Tato řešení zaměňují symptomy za příčiny, a tak má výsledek pouze omezený úspěch (Grofovi 1999). Nestačí nakrmit hladovějící, snížit emise kysličníku uhličitého, nebo snížit výdaje na zbrojení. Nejdříve je nutné pochopit psychologické a společenské síly, které jsou za danou situaci odpovědné, a to především, že politické, kulturní, ekonomické nebo ekologické problémy, kterým čelíme, „odrážejí emoční, morální a spirituální stav soudobého lidstva" (Grofovi 1999, 239). Naději na přežití můžeme hledat $\mathrm{v}$ rámci nového metaparadigma$t u$, které se pomalu ve vědě i ve společnosti otevírá a přináší základní změnu v našem myšlení, vnímání a v hodnotách směrem $\mathrm{k}$ holistickému a ekologickému úhlu pohledu (Capra 2002). Fritjof Capra aplikoval Kuhnovu definici vědeckého paradigmatu na definici společenského paradigmatu (2004). V této souvislosti je nutno poznamenat, že přicházející změna paradigmatu je něčím víc, než jen vědeckou revolucí. Tentokrát se nejedná o nic menšího, než o znovunalezení hodnot a smyslu, o který jsme byli my, jako nositelé lidské historie, připraveni. Téma spirituality je jedním $\mathrm{z}$ nově nastupujících témat 21 . století. Spiritualita, která byla $\mathrm{z}$ karteziánsko-newtonovského pohledu na svět vyřazena, prožívá renesanci. Je více než dost důkazů o tom, že transcendentální impuls je nejdůležitější a nejmocnější silou, která v člověku existuje. Systematické odmítání a potlačování spirituality, tak charakteristické pro moderní západní společnost, kritickým způsobem přispívá k odcizení, existenciální úzkosti, individuální společenské psychopatologii, kriminalitě a sebedestruktivním sklonům moderního lidstva (Grof 2004). V jádru celé globální krize se bezprostředně ukazuje, jak je moderní člověk vzdálený sám sobě a duchovnímu způsobu života.

\section{SPIRITUALITA A SOUČASNÁ VĚDA}

Systémový pohled na život napovídá, že abychom získali zpět plné lidství, musíme znovu obnovit zkušenost sounáležitosti s celým pletivem života. Toto „znovunapojení je pravou podstatou spirituálního základu nového paradigmatu (Capra 2004). Peter Russell, teoretický fyzik a experimentální psycholog z Cambridge poznamenal, že: „Budoucí rozvoj lidského druhu nesměruje ven do vesmíru, ale dovnitř, do skrytých hloubek vědomi" (Russell 2008, 93). Už Teilhard de Chardin kdysi naznačil, že přijde doba, kdy si poznávající člověk konečně všimne, že člověk jako předmět poznání, je klíčem k celé prírodní vědě (Teilhard de Chardin 1990). Spiritualita se zabývá také skutečnostmi, které sítí vztahů souvisí s oblastmi, pro jejichž zkoumání jsou kompetentní přírodní vědy. Díky přírodovědeckým teoriím získává spiritualita rámec a zároveň plodné propojení. Aby spiritualita nezůstala pouze vágní a mlhavou spekulací, je potřeba objasnit široký základ nového vnímání reality, kte- 
rý ve vědě otevírají a rozpracovávají speciální obory. Změna paradigmatu souvisí s objevy $\mathrm{v}$ kvantové fyzice, jež nás vedou $\mathrm{k}$ pohledu na svět, „který je velmi podobný pohledi̊m mystiků všech dob a tradic" (Capra 2003, 23), se systémovým myšlením, jehož průkopníky byli biologové a který se ve své nejhlubší podstatě stává spirituálním (Capra 2005) a s dalšími objevy ve speciálních vědách. Teorie relativity i kvantová fyzika, dva velké posuny paradigmatu v moderní fyzice, vzešly $\mathrm{z}$ anomálií $\mathrm{v}$ chování světla a naprosto posunuly úhel pohledu daleko za newtonovskou fyziku. Prostor už není trojrozměrný a čas není lineární. Nastupuje čtyřrozměrné kontinuum zvané časoprostor. Hmota na úrovni subatomových částic vykazuje paradoxní povahu vlny i částice a je jen málo hmotná, pokud vůbec (Russell 2008). Duální pojetí částic souvisí s probabilistickým přístupem. Svět pevných hmotných objektů se na subatomové úrovni rozplývá do struktury vln pravděpodobností, a to nikoliv objektu, ale spíše vzájemných vztahů subatomových částic (Grof 1992c). Podle příspěvku Wernera Heiseberga zaniká i ideál objektivního popisu jevu. Na kvantové úrovni není možné vynechat vliv pozorovatele a klasická představa objektivity vědy už nemůže být obhájena (Capra 2003). Dalším zásadním objevem moderní fyziky byla „kvantová teorie pole“. Částice nelze oddělit od prostoru, který je obklopuje, představují zhuštění spojitého pole, které je přítomno všude $\mathrm{v}$ prostoru. Teorie pole ukazuje, že částice mohou spontánně vznikat z prázdna a zanikat do prázdna. Objev dynamické kvality „fyzikálního vakua“ je značně důležitý, protože naznačuje stav prázdnoty a nicoty, který potenciálně obsahuje všechny formy světa částic. Tento pohled souzní s moudrostí starobylých východních filosofií (Grof 1992c, Capra 2003). Počáteční objevy ve fyzice napomohly rozvoji dalších odvětví vědy. Postupné formulování jazyka pro porozumění složitým, vysoce integrovaným živým systémům se inspirovalo tvarovou psychologií, nově vzniklou ekologií, kybernetikou, teorií informace, neurologií a kognitivní vědou. Jako zásadní pojmy jsou vnímány sítová dynamika a její nelinearita a samoorganizace. První vlivnou teorií samoorganizujících se systémů byla Prigoginova teorie disipativních struktur. Disipativní struktury ve stavu vzdáleném od rovnováhy mohou ustanovovat nový řád a dokonce se i vyvíjet ve stále složitější struktury. Neurologové Humberto Maturana a Francisko Varela nazvali koncepci samoorganizace a sebeutváření živých systémů teorií autopoiesis. Své nejpozoruhodnější vyjádření si našla v paralelně vzniknuvší hypotéze Gaia chemika Jamese Lovelocka a mikrobioložky Lynn Margulisové. Idea, že planeta Země je živoucím a sebeorganizujícím se systémem, který řídí sám sebe, skládá se ze všech organismů, hornin oceánu a atmosféry, jež jsou úzce propojeny a společně se vyvijí, se potvrzuje. Lovelock zjistil, že život, který se podle původní představy konvenční vědy přizpůsoboval podmínkám na planetě, směřuje $\mathrm{k}$ nějakému cíli. Podmínky na povrchu udržuje takové, aby byly co nejvýhodnější pro současný život (Lovelock 2008). Stáří Země se odhaduje na 8 až 15 miliard let. Produkce tepla Sluncem vzrostla od doby vzniku života na Zemi, tedy před asi 4 miliardami let, o 25 procent. Země přesto udržela teplotu stálou a příznivou pro organismy, stejně tak jako salinitu oceánů, složení atmosféry a celý složitý systém Země. „Lovelock pochopil, že zemská atmosféra je otevřeným systémem vzdáleným od rovnováhy, charakterizovaným stálým tokem energie a látek. Jeho chemická analýza zjistila skutečný charakteristický znak života“ (Capra 2004, 102). Maturana a Varela př̀i hledání odpovědi na uspořádání živého systému, dochází $\mathrm{k}$ závěru, že sítové uspořádání je základem organizace života. Jejich teorie Santiago říká, že živé systémy jsou kognitivní systémy a život jako proces je procesem poznání. Toto tvrzení platí pro všechny organismy, at' už s nervovým systémem, nebo bez něho. Nové pojetí procesu poznání zahrnuje vnímání, emoce a činnost a v lidské ř́iši je to také jazyk, pojmové myšlení a všechny další atributy lidského vědomí. Mysl není věc, jako mentální proces je procesem poznání, který je vlastní hmotě na všech úrovních života a který je totožný s procesem života. Mozek je specifická stavba, pomocí níž se tento proces uskutečňuje. Vztah mezi myslí a mozkem, je vztah mezi procesem a stavbou (Capra 2004, 249). Z pohledu evoluce vysvětluje vztah mezi vědomím a formou podrobně Peter Russell. Vědomí je podle něj základní vlastností prrírody a vlastnost vědomí je přítomna napříč celým evolučním stromem. Tedy vědomí není něco, co se objevilo s lidskými bytostmi nebo $\mathrm{s}$ obratlovci, to co se $\mathrm{v}$ průběhu evoluce objevilo, nebyla schopnost vědomí, ale formy vědomí. Vyzrálejší a vyzrálejší. Russell podrobně rozpracovává teorii, která vede od bakterií, zaznamenávajících jen ty nejobecnější charakteristiky a změny svého prostředí, přes savce, kteři s vyvinutím limbického systému už mohou prožívat pocity, jako jsou strach, vzrušení a citové pouto, až k rozvoji mozkové kůry, ve které se stavba pro vnímání podstatně zdokonaluje, aby dovedla lidstvo $\mathrm{k}$ nejdůležitějšímu skoku. Uvědomění si sama sebe. Začali jsme si uvědomovat své vlastní myšlení, zkoumat vnitřní svět mysli a nakonec, objevovat podstatu samotného vědomí (Russell 2008).

Obraz vesmíru a podstaty skutečnosti prochází ve vědě současnosti dalekosáhlými změnami. Kvantová fyzika i speciální vědy nabízejí řadu pozoruhodných témat a přesahů. Pro spiritualitu z těchto bádání vyplývají zajímavé podněty. Výzkumy v neurovědách se zabývají například i výzkumem existence tzv. „bodu Boha“ v lidském mozku. Michael Persinger a Vilayanur Ramachandran prokázali, že toto vestavěné duchovní centrum je umístěno v nervových spojích spánkových laloků. U subjektů vybíraných napříč kulturami při diskuzi o duchovních a náboženských tématech souvisejících s danou kulturou zaznamenali zvýšenou aktivitu těchto mozkových oblastí. Činnost spánkových laloků byla původně zaregistrována v průběhu mystických vizí epileptiků a při výzkumech s LSD. Tyto závěry nedokazují existenci Boha, ale poukazují na skutečnost, že lidský mozek se vyvinul tak, aby mohl klást nejvyšší otázky a využíval citlivost pro širší hodnoty a smysl (Zohar - Marshall 2003). Velice diskutovaný nejen v neurovědách je i Karlem Pribramem vyvinutý „holografický model mozku“ (Pribram 1999). Pribram, původně neurochirurg, poté vưdčí osobnost bádání a objasňo- 
vání struktury a funkce mozkové kůry, poukazuje na skutečnost, že mozek neukládá informace místně, ale holograficky a objasňuje, proč nelze v mozku přesně lokalizovat vizuální pamět. Pribram použil Gaborův princip třírozměrné fotografie (Clegg 2009) a přinesl důkazy, že jedna z vlastností receptivních polí buněk v primárním vizuálním kortexu může být vyjádřena v termínech Gaborových elementárních funkcí (Pribram 1999). Pribramův model má další zajímavou návaznost týkající se „signální nelokality“. V subatomární fyzice jde o kauzální spojení mezi prostorově oddělenými jevy pomocí signálů. Podle teorie relativity není možné předat signál rychleji, než rychlostí světla. Princip lokálnosti je pro nás jeden ze samozřejmých principů běžného života. Cosi, zvuková vlna, kámen, putuje od A do B a nutnost, že musí putovat, zabere nějaký čas. Tam, kde je signál takto předáván, jde o lokální spojení (Clegg 2011), ale v kvantové fyzice se objevila i nelokální spojení. Zdá se, že vzdálené částice si nějak dokážou vyměnit informace okamžitě, nebo se chovat jako součásti jediného celku. Tato spojení se nedají matematicky predikovat (Ondok 2001). „Nelokální informace o psychickém vesmíru poskytují chybějící spojení mezi objektivní vědou a subjektivními zkušenostmi včetně zkušeností mystických. Na základě principu nelokality a v rámci kvantové anténní soustavy cytoskeletální síté, je mozek $v$ souladu s celým vesmírem"(Frecska 2005, 216-217). Ede Frecska ve své pozoruhodné studii poukazuje na dva režimy mysli pro získávání lidského vědění. Perceptuálně-kognitivně-symbolický způsob zpracování informací, který je výlučným modem v západní společnosti, charakteristickým pro obyčejné stavy vědomí a prímý-intuitivní-nelokální režim související s polyfázovostí změněných stavů vědomí a získávající informace nepřímo. Obdobně pojímá dva způsoby přijímání informací o Universu i Stanislav Grof: V hylotropním režimu poznáváme svět prostřednictvím smyslového vnímání a analýzy a syntézy dat a v holotropním stavu vědomí přímou identifikací se všemi aspekty světa (1992a). Důsledkem těchto hypotéz je i vyzdvižení a uznání výpovědní hodnoty dřive nezařaditelné intuice, která náleží zcela do nelokálního kanálu. Tyto výklady naznačují, že nelokalita, je ve skutečnosti základním principem vesmíru, což znamená, že celý vesmír, je jedním vzájemně propojeným celkem. Pokud mozek a naše mysl skutečně obsahuje celý kosmos jako hologram, získává věčná moudrost „,o je nahoře, je i dole“ nebo „co je uvnitřr, je i vně zřetelně jiný rozměr, který může být v budoucnu v souladu se západní vědou (Frecska 2005, Grof 1992b). Tyto závěry odpovídají i mé osobní zkušenosti. Mnohokrát v životě jsem ve spontánních mimořádných stavech vědomí, at’ už jimi byly vize, intuice, sny, obrazy vyvstávající v relaxaci či meditaci, nebo těžké období osobní psychospirituální krize, ze své vlastní mysli získávala pravdivé informace o vzdálených dějích a obrazech, které jsem neměla možnost získat jinou, než nelokální cestou.

Nové vidění reality ve vědě, nepřináší jenom údiv a úžas nad naznačovanými vizemi, ale spěje i k ocenění hodnoty niterné účasti, bez které, jak řekl filosof Henryk Skolimowski, atrofujeme a hyneme (Skolimowski 2001).

\section{SPIRITUALITA A NÁBOŽENSTVÍ}

Pohyby v Západní společnosti a kultuře směrem k novému myšlení zaznamenáváme od 60. a 70. let minulého století. Šedesátá léta urychlila rozvoj různých sociálních hnutí, ekologického uvažování, feministických směrů a řady dalších proudů. Od té doby se setkáváme s velkým nárůstem zájmu o spiritualitu a o osobnostní zrání. Změnu ve společenské atmosfére můžeme zaregistrovat $\mathrm{v}$ jakémkoli knihkupectví, at už specializovaném nebo obecném, kde oddělení zaměřená na osobní rozvoj a duchovní nauky pojímají velká množství titulů: východní filosofie, alternativní směry lidové spirituality, léčitelské aktivity, obsahy tajných nauk starobylých kultur, meditace, holistický přistup ke zdraví, filosoficky pojaté novodobé výzkumy v různých vědách a další. $Z$ těchto oddělení můžeme ale také vyčíst, že na akademické půdě ještě neexistuje jednotná koherentní koncepce spirituality, takže odborné a vysoce erudované studie můžeme bohužel najít i př́mo vedle knih nejpokleslejší esoteriky.

Oblast duchovna $\mathrm{v}$ současné době nachází své nové a nově prožívané místo a s ním i nové formy. Na konci dvacátého století se ve společnosti ustálil dnes nábožensky neutrálně vnímaný pojem spiritualita. Nahradil pojem religiozita silně spjatý s institucí náboženství. Latinský kořen spiritualitas se objevuje v novozákonních pavlovských listech, jímž se z řečtiny překládá pneuma, řecké označení ducha, s př́islušným adjektivem pneumatikos. To znamená: „Kdo se oddá Pánu, bude s ním jeden duch“ $(1 \mathrm{~K} 6,17)$, nebo že „víra v Pána je od Ducha a v Duchu“ (1K 2,10nn). V latinském spirare zjištujeme i původ související s dýcháním. Souvislost s dechem můžeme nalézt $\mathrm{v}$ mnoha dalších jazycích. Vzhledem $\mathrm{k}$ dobovému posunu významů je potřeba si uvědomit, že termíny „Duch“ a „duchovní v pavlovské teologii nestojí proti pojmům „fyzický“ nebo „materiální“. Platí zde, že stojí proti všemu, co se protiví Duchu božímu, což může být jak tělo nebo fyzická realita, tak např́ílad i mysl nebo vůle. Dualitu hmoty a ducha vyostřili scholastici, nicméně pavlovský koncept nebyl zcela nahrazen. Od třináctého století existují oba vedle sebe. Tehdy se také objevuje pojetí třetí, v jehož rámci se termínu spiritualita začalo používat k označení kněžského stavu a do šestnáctého století byla právě tato forma nejfrekventovanější. Teprve století sedmnácté vrací pojem spiritualita zpět $\mathrm{k}$ aplikaci ve vztahu k duchovnímu životu a plně se navrací až v prvních desetiletích minulého století. Týká se samotné povahy duchovního života, potřeby oddělit dogma a studium, a hlavně sílícího důrazu na náboženské vědomí a na zkušenostní sféru. Roky 1920 (založení široce uznávané Revue d'Ascetique et Mystique) a 1932 (první vydání Dictionnaire de Spiritualité, který vycházel na pokračování) se posílilo seriózní postavení tohoto pojmu. Po II. vatikánském koncilu bylo heslo spiritualita zapsáno do teologického slovníku (Sheldrake 2003).

V šedesátých letech minulého století se v euroatlantské společnosti rozšíril odpor proti etablovanému náboženství. Lidé se začali odklánět od každodenní, ortodoxní, především křestanské, praxe. Pocit svazování náboženskými kulty a uvědomění si rozporuplných rolí církví v dějinách lidstva, vedlo 
mnohé lidi k poznání, že učení těchto náboženských institucí se rozchází s praxí skutečně cítěného duchovního života. Sekularizací Západu dochází k vytvoření kultury do značné míry nezávislé na tradičním náboženství. Náboženský výklad světa již není základním a dominantním způsobem myšlení a stává se pouze osobní záležitostí jedince, ale sekularizace kultury ještě neznamená vymizení duchovních obsahů. Zinnbauerovo pojetí (ríčan 2007) dobře vystihuje současný vztah spirituality a náboženství. Spiritualita je podle něj širší pojem a náboženství, jako možný projev spirituality, zahrnuje. Podle Říčana nenáboženská spiritualita obsahuje prožitky nezávislé na jakékoli organizaci a učení a člověk je může prožít při vrcholové zkušenosti v př́rodě, milostném vztahu, při porodu, pod vlivem psychoaktivních látek a jiných existenciálních zkušenostech (Říčan 2007). Paradoxně tedy se sekularizací Západu dochází k renesanci spirituality (Nešpor - Lužný 2007). Vyvázáním spirituality z pevně daných církevních mantinelů, dochází k rozvoji mnoha nových duchovních hnutí a směrů. V komplexu kulturního dění má každá doba specifickou formu projevů duchovních obsahů. Naše doba objevuje tzv. „světskou spiritualitu“. Tedy „...tvoření duchovních obsahů jaksi skrze život sám“" (Babyrádová 2006, 25). Ale tato specifická dějinná situace není pro jednotlivce bez nebezpečí. Obecná rozsáhlejší vzdělanost $\mathrm{v}$ působnosti religionistiky, spirituality a jednotlivých světových tradic je v západní společnosti na nízké úrovni a probuzená spiritualita může mít tendence sklouzávat $\mathrm{k}$ fundamentalismům a jediným pravdám, a také $\mathrm{k}$ zastřenému egoismu, individualizované a narcistické spirituality.

\section{SOUČASNÉ VYMEZENÍ POJMU SPIRITUALITA}

Popisně se užívá ve vztahu k označení duchovních a náboženských směrů a hnutí, tedy religiozit, nebo nově spiritualit. Tento úhel pohledu je nazírán sociologicky a pojmem spiritualita označujeme socializaci a institucionalizaci prožitku.

Pokusíme-li se vymezit pojem spirituality obsahově, setkáme se v odborné literatuře s celou řadou definic. Definovat spiritualitu je složité a nikdy toho nelze dosáhnout vyčerpávajícím způsobem. Jednak v sobě oblast, jíž se dotýkáme, ukrývá jistou částečnou nepřeložitelnost, kdy narážíme na hranice schopnosti lidského vyjádření (Otto 1998, Fromm 2003) a za druhé se vzhledem k současnému živému diskursu naplnění „pojmového kontejneru“ spiritualita stále tvoří.

V nejobecnějším smyslu je zpodstatnělá spiritualita vnímána jako sám duchovní obsah, jako např́ílad výrok: Spiritualita je nadějí pro duchovně strádající lidstvo současnosti (Štampach 2006).

Původní pojetí abstrahované především z teologického zázemí pojímá spiritualitu jako prožitkové jádro náboženství (Říčan 2007), jako osobní prožívání vztahu k transcendentní skutečnosti. Spiritualita je nahlížena jako specifická zkušenost s posvátným (Halík). Bohatá škála definic západních badatelů naznačuje, že spiritualita představuje mimořádně důležitou, vrozenou dimenzi života (Wilson 1993) a je nedílnou součástí lidské existence. Pramení z vnitřního zdroje, který má v sobě každý a její nepominutelnou částí je osobní prožitek. Přestože se chápe jako záležitost individua, zdroj je společný všem lidem a obecně universálnímu řádu věcí. Je možné ji chápat jako kvalitu života, bytí a prožívání, jejíž součástí je vědomí nekonečna, nevyslovitelného a nepopsatelného.

Zajímavé je sledovat proměny pojetí spirituality v kontextu proniknutí východních filosofií na Západ. V obsahovém vymezení spirituality je ve výše citovaných náhledech na spiritualitu položen největší důraz na autentickou vnitřní zkušenost, která byla nadlouho vyřazena ze společností akceptovaných forem získávání zkušenosti a na svobodu individuálního vyjádření, kterou přinesla privatizace náboženství. S příchodem východních filosofií se v pojetí západní spirituality objevuje další akcent, a tím je orientace na osobní aktivitu jednotlivce na cestě $\mathrm{k}$ transcendenci. Jistá statičnost $\mathrm{v}$ původních pohledech na spiritualitu, nebo posvátno, souvisí $s$ dědictvím křestanství, pro které je na vnitřní cestě jednotlivce zásadní očekávání a přijetí „milosti“. Východní učení oproti tomu apeluje na vlastní práci, kdy přes nalezení sebe sama docházíme k poznatku, že se každý podílí na kosmickém životě a nachází v něm své místo. André van Lysebeth, autor řady knih a publikací o józe, ř́ká: „Duchovnost je probuzení $k$ životu, $k$ tomu pravému životu“ (Lysebeth 1999, 285). Duchovní život je podle něj jen více či méně probuzený život různého stupně, intenzity a rozsahu. „Jedinou skutečnou duchovností je rozvíjení všech rovin bytí, nebot' automaticky vede $k$ vnitřnímu světu, kde člověk objevuje největši bohatství. Rozvijet všechny aspekty své osobnosti znamená probudit se ve všech rovinách" (Lysebeth 1999, 284). Ovládnout své tělo, rozvinout intelekt $\mathrm{v}$ rozumných proporcích, abychom neztratili intuici a citlivost, dát prostor citové stránce, tedy schopnosti cítit lásku. Vrcholem je navázání kontaktu sám se sebou, tzn. s němým svědkem s tím, „kdo to všechno vidí“. Tedy nalézt přímé vnitřní vnímání (Lysebeth 1999).

Až překvapivý, přesto korespondující se současnou moderní fyzikou a zároveň starobylou moudrostí světových nauk, je posun pojetí spirituality v postmoderní době. Nové paradigma $\mathrm{v}$ poznávacích teoriích některých badatelů nepřímo rozšiřuje původní pojetí spirituality. Spiritualita není jenom podstatná dimenze osobnosti, schopnost otevřeného vědomí, vrcholová zkušenost, nebo nejryzejší prožitek „čistého byti“ ve změněném stavu vědomí. Zdá se, že v současné době je potřeba obohatit vnímání spirituality $\mathrm{v}$ obecném povědomí ještě o jeden podstatný aspekt. Je důležité si uvědomit, že spiritualita je také, a možná př̀edevším, proces. Proces kultivace duše. Odillo I. Štampach použil termín „proces zlidštováni“ (Štampach 2006). Spiritualita je součástí procesu kulturní evoluce. Evoluce očima Teilharda de Chardin směřuje ke kolektivnímu duchovnímu procesu. „Přes hranice národů a ras už probíhá nevyhnutelné scelování lidstva" (Teilhard de Chardin 1990, 230). Také americký filosof Ken Wilber ve své systematické, obsáhlé a ucelené teorii obecného výzkumu evoluce ve všech sférách, ztotožňuje evoluční proces se spiritualitou, ve smyslu evoluce vyšších etap vědomí, které můžeme nazvat duchovními. Po vzoru Hegela, Schelinga, Aurobinda a dal- 
ších evolučních teoretiků Západu i Východu uvažuje o evoluci jako o „působícím Duchu“ (Spirit-in-action). Duch zde nepředstavuje konkrétní etapu, ideologii, specifického boha či bohyni ale spíše proces, který se postupně odhaluje, rozvijí a uvědomuje se s každou další etapou vývoje sám v sobě. Ale právě ve vy̌šíích (či hlubších) etapách vývoje si Duch stále více uvědomuje sám sebe a začíná chápat svou vlastní pravou podstatu. Tyto stupně představují naše vlastní nejvnitřnější potenciály (Wilber 2010).

\section{ROLE SPIRITUALITY}

Z teorie Kena Wilbera můžeme vyč́st i jednu z možných odpovědí na otázku abstrahovanou z vystoupení Davida Camerona: „Proč si lidé myslí, že jejich chování nemá žádné důsledky?“ A: „Proč mají pocit, že jim svět něco dluží?“. Kulturu $\mathrm{v}$ níž lidé podléhají mánii domáhat se egoistických práv, aniž by chtěli plnit nějaké povinnosti, nazval kulturou narcismu a regrese. $V$ jeho rozsáhlé mapě našeho světa je moderní svět označen jako fádní rovina, která nerozeznává stupně vědomí, hloubku, hodnoty a ceny. V moderně, jak rríká, se chceme stát celkem, aniž bychom mínili stát se částí čehokoli. Neuznáváme žádnou hierarchii v rámci vztahů fyziosféry, biosféry a noosféry, $\mathrm{z}$ níž pro nás sice vyplývají relativně větší práva, ale tato práva vyžadují i relativně větší povinnosti a zodpovědnost (Wilber 2010). Jsme fragmentováni, necítíme vzájemné propojení a chceme žít jen sami za sebe. Chybí nám ontické filosofické povědomí o důležité skutečnosti, že selhání při plnění těchto povinností, znamená naše sebezničení právě proto, že existujeme pouze $\mathrm{v}$ rámci širši sítě vzájemně nedělitelně provázaných vztahů. Přestože Wilber uznává hodnotu racionální etapy a jejích nepopiratelných úspěchů $\mathrm{v}$ evolučním procesu, jako je např́klad vzrůst individuálních i společenských svobod a s tím souvisejících osvobozeneckých hnutí a vyzdvihuje modernu s jejím objevem "bytí rozvíjeného v evolučním čase" (Wilber 2010, 344), dodává, že neštěstím moderny je skutečnost vynechání Ducha neboli spirituálního procesu z ústřední myšlenky evoluce. Vyloučili jsme sílu, která lidský život vyživuje a posiluje.

O tom, jak zásadní toto opomenutí je, svědčí stále častěǰsí důraz na roli spirituality př̀ řešení současné situace. Globální krize je dnes takového rozsahu, že se s ní nedokážou vypořádat žádné další fyzické evoluční změny. Lidský rozum vytvořil obrovský pokrok v technologii a technologie tak zvýšila nejen naši moc měnit svět, ale také chyby $\mathrm{v}$ našem myšlení. Jsme zahlceni problémy, které dokáže rozkrýt pouze duchovní evoluce (Hickman 2010). Řešení se nalézá v dosud neprobádaných částech našeho mozku a tak jsou očekávány spiše objevy psychofyzikální, které, zdá se, potvrdí, ,jak daleko za čistě fyzické je lidský mozek vybaven jit" (Hickman 2010, 11). Spirituální učení a tradice mystického moudra sdílejí až pozoruhodnou podobnost napříč kulturami a mnohé jsou dodržovány po tisíciletí. Pozoruhodná existence flexibilních společných rysů je empiricky potvrzená. „Jelikož přmín-intuitivní-nelokální kanál postrádá symbolicko-ling- vistickou meditaci (verbální, logickou a zprostředkovanou vizuálním jazykem), má univerzální charakteristiky a vykazuje větši transkulturní podobnost, i prestože existuje kulturně-specifický výklad" (Frecska 2010, 218). Základní nelokalita mysli a vesmíru se hroutí ve stavu normálního vědomí a k jejímu zhroucení vede př̀edevším vnímání času a prostoru. Tato skutečnost $\mathrm{v}$ souvislosti s absencí osobní zkušeností badatelů mechanisticky pojímané vědy s neobvyklými stavy vědomí, objasňuje, proč byla jako jediná možná brána v potaz akademická vysvětlení racionální epochy. Úzký materialistický pohled nazírá na transpersonální stavy a prožitky jako na patologické projevy funkce mozku, nebo napríklad jako na berličky, které přinášejí $v$ nepřátelském světě útěchu. Tyto konstrukty jsou dnes překonané a ve světle současných výzkumů neudržitelné (Grof 1992). Ověřili jsme si, že intelektuální poznání je sice nezbytné, ale samo o sobě nestačí $\mathrm{k}$ hlubokému porozumění. Kultivovali jsme intelekt a jako západní společnost jsme naprosto rezignovali na kultivaci mysli. Transpersonální filosofové ř́íkají, že mysl sama musí projít multidimenzionální průpravou a že hluboké sebepoznání přichází ve vícestavovém prožívání. Přesun $\mathrm{k}$ jednostavové společnosti a ztráta rituálem chráněných vícestavových prostorů vědomí má pro naši kulturu nebývale výrazné následky. Naše relativně monofázová společnost je zaměřená na obvyklý bdělý stav vědomí, který je pokládán za jediný prìijatelný a normální a je i jedinou fází vědomí vhodnou pro rozmnožování informací o světě. Antropologické výzkumy poukazují na skutečnost, že většina lidských společenství vyžaduje integraci zkušeností mnohočetné reality prožívané některými či všemi př́slušníky skupiny skrze polyfázové vědomí (Laughlin - McManus - Shearer 2011). Na základě studia těchto stavů, už dnes víme, ,jak neuvěritelně jsme podcenili plasticitu lidského vědomí a rozsah škály jeho potenciálních stavi̊ "(Walsh - Vaughanová 2011,30) a následné možné pozitivní dopady na celou kulturu. Transpersonální zážitky mohou výrazně snížit stupeň agrese a teorie a praxe transpersonální psychologie by mohly výrazně přispět ke zmírnění globální krize. Takový př́stup $\mathrm{k}$ životu může vést $\mathrm{k}$ vnitřní přeměně $\mathrm{a}$ individuaci. Udává se, že v důsledku kontemplativní introspekce, vnitřní práce na sobě a další kultivace duchovní stránky, tedy osobnostního dozrání, přichází hluboké porozumění životu a etické chování vyplývá spontánně. Lidé mají tendenci rozvijet $v$ sobě úctu a respekt ke všem formám života, tím se rodí ekologický př́stup ke světu a přichází nově zažité porozumění pro jednotu všech věcí, ohleduplnost, toleranci a soucit. Postoje typické pro kultivovanou spiritualitu lze chápat jako protiklad netolerance, neúcty $\mathrm{k}$ životu a mravního úpadku, které jsou hlavními symptomy globální krize. Stanislav Grof, spoluzakladatel transpersonální psychologie a předseda Mezinárodní transpersonální společnosti, byl $\mathrm{v}$ průběhu svých výzkumů podle svých slov svědkem hluboké vnitřní přeměny mnoha lidí. Lidé, kteří prožili hlubokou transpersonální zkušenost, téměř bez výjimky přijali širši pohled na podstatu člověka a kosmu. Jako jednu z nejvýznamnějších změn, udává nové hodnocení úlohy spirituální dimenze ve vesmíru a v lidském životě (Grof 1992, 2004). Současný rozvoj transperso- 
nálních mnohastavových disciplín nabízí pochopení a vyjádření transpersonálních zkušeností a jevů, které jsou i v naší společnosti prožívány, ale byly dlouhou dobu odmítány jako iracionální, či patologické. Důležité a mimo odbornou komunitu téměř nediskutované téma, je téma psychospirituálních krizí, které pokud nejsou rozpoznány, jsou často zaměněny za psychotické stavy a jsou na ně aplikovány metody, které tyto zážitky potlačují a ukončují. Jedinci ve skutečnosti netrpí duševní nemocí, ale procházejí vývojovou krizí, a pokud dojde $\mathrm{k}$ potlačení krize, veškerý vývojový potenciál je znehodnocen a naopak nastupují dlouhodobé chronické obtíže a závislosti na utišujících lécích (Grofová - Grof 2011). Jako psychospirituální krize jsou označovány epizody neobvyklých zkušeností, které zahrnují změny vědomí, změny vnímání, myšlení, emoční změny a změny dalších psychosomatických funkcí. Lidé v těchto epizodách procházejí zkušenostmi přesahujícími obvyklé meze prožívání vlastního „Já“. V Kalifornii vzniklo v roce 1980 první středisko pro vytvoření pomocného a podpůrného programu pro stavy duchovní tísně a psychospirituální krize Společnost pro spirituální rozvoj (SEN). Jako alternativu tradičního psychiatrického systému ho vytvořila Christina Grofová. V České republice od roku 2004 působí občanské sdružení Diabasis a sjednocuje zájem odborníků psychologů, psychiatrů, psychoterapeutů a dalších pomáhajících profesí i laiků ${ }^{1}$.

Současní badatelé (Abraham - McKenna - Sheldrake 2008; Capra 2002; Grof 2004; Metzner 2011; Russell 2008, 2011; Walsh - Vaughanová 2011) uznávající spirituální dimenzi jako zásadní katalyzátor možných změn budoucnosti pro přežití lidstva se téměř jednomyslně shodují na myšlence, kterou nejlépe vystihl Ken Wilber „Když chaotické tlaky nepovedou k sebetranscendenci, povedou k seberozpuštěni " (Wilber 2010, 349). Objevují se zde dvě možnosti volby, tak jako v každé době, která dozraje $\mathrm{k}$ evolučnímu skoku. Wilber varuje, že jsme nikdy nebyli blíž zmaru, právě proto, že fádní rovina nepřipouští existenci vertikální dimenze vědomí, popírá vnitřní transformaci a vývojové stupně vědomí tvořících oprávněnou součást lidského kulturního kapitálu. Abychom mohli účinně zvládnout současnou krizi, je nezbytné mít globální vědomí. Globální vědomí je součástí vnitřního rozvoje, součástí spirituálního procesu. Bez vnitřního růstu problémy přetrvávají. Jinými slovy, aby se jednotlivci mohli stát významnou silou v rámci globální reformy, „musí významný počet jednotlivců dosáhnout postkonvenční, světocentrické vývojové úrovně “ (Wilber 2010, 350). Wilber zmiňuje významnou část jednotlivců. Současné výzkumy teorie chaosu naznačují nadějnější poselství, které nám předává Karl Pribram. V devadesátých letech si položil otázku: Jak se máme chovat v tak složitém systému jako je naše současná společnost? Jeho spolupracovníci v počítačových simulacích pokračujících až $\mathrm{k}$ tomu, co bychom nazvali chaosem, dospěli $\mathrm{k}$ závěru, že pokud budou chtít tento stav kontrolovat a občas zasáhnout, stačí, aby ovlivnili jen jednu malou část systému. Zbytek systému $\mathrm{v}$ patřičném čase reaguje a dočasně se stabilizuje (Pribram

1 www.diabasis.cz
1992). Karl Pribram nabádá, že pokud alespoň někteř́ začneme pracovat na své vlastní stabilizaci, tedy individuaci, můžeme celý systém, ve kterém se naše společnost nachází, vyvést $\mathrm{z}$ chaosu. Tento závěr podporuje i tzv. bootstrapová teorie částic. Materiální svět je viděn jako dynamická sít vzájemně propojených událostí. Žádná z vlastností jakékoli části této sítě není základní, všechny plynou z vlastností ostatních částí a všeobjímající soudržnost jejich vzájemných vztahů určuje strukturu celé sítě. Člověk-pozorovatel je tak její integrální částí (Capra 2002). Je-li svět sít relací, jak o tom mluví Geoffrey Chew a v teoriích živých systémů Maturana, Varela, Lovelock a další a jsme-li podle výzkumů transpersonálních vědců a neurologů mikrokosmem, který v jakémsi holografickém obrazu obsahuje i informace o makrokosmu, pak nejsme jen malá nemohoucí já, ale jsme součástí celkového vědomí. Uvědomíme-li si svoji změněnou pozici oproti newtonovsko-karteziánskému paradigmatu, ve kterém jsme jako bytosti vystupovali právě jako pouhé nevýznamné nic, už jenom tato zažitá informace může radikálně změnit postoj $\mathrm{k}$ sobě samému, k druhým i ke světu, ve kterém žijeme a otevřít osobní cestu ke spirituálnímu procesu. Jedním $\mathrm{z}$ důsledků atrofie morálních, etických a duchovních hodnot byla právě rezignace na účast a ztráta smyslu.

\section{SPIRITUALITA V KULTUROLOGICKÉ KONCEPCI}

Pro nové myšlení je charakteristická změna paradigmat jednotlivých věd, mezioborová spolupráce a interdisciplinarita. Tedy transdisciplinární projekty. Setkáváme se s pokusy o novou syntézu, o propojení vědeckého př́rodovědného a kulturního poznání s filosofickou interpretací a Odilo I. Štampach zmiňuje i propojení s kontemplací (Štampach 1993).

V novém paradigmatu je spiritualitě připisována zásadní role propojujícího, horizontálně

i vertikálně prosakujícího tmelu. K posunu ve vnímání spirituality došlo poměrně nedávno. Není mnoho koherentních teorií, nebo výzkumných metodologií, které by tento konstrukt vysvětlovaly a jednotná koncepce pojetí studia spirituality chybí. Henryk Skolimowski upozorňuje, že vzhledem k zatím neexistující oficiální akademické linii, která by podpořila duchovní hodnoty a znovu tak vyvážila materiální a duchovní stránky našeho světa, dochází k jistému typu atrofie konfigurace kultury. K atrofii morálních, etických a duchovních hodnot jako nedílných součástí dalšího rozvoje kultury (Skolimowski 2001).

Původně byla interpretací fenoménu spirituality pověřená dominantně teologie a následně religionistika. Rozsáhlý vědomostní základ o historicky a kulturně odlišných náboženských a spirituálních formách položil v minulém století historik náboženství Mircea Eliade. Jeho cílem bylo svými studiemi ukázat cestu obnovenému duchovnímu hnutí na Západě.

První odborné pracoviště, které se spiritualitou začalo zabývat, a přijalo ji do svého výzkumného záměru, byla Americká psychologická asociace, což je sdružení amerických psychologů. V roce 1976 přijala Psychologii náboženství do zařazení 
vědních oborů jako tzv. 36. divizi psychologie. Ta v 80. letech rozšírila program týkající se náboženství i na spiritualitu a v klasifikaci nemocí ve vydání z roku 1994 figurují problémy s náboženstvím a spiritualitou. Lze je zkoumat a léčit. V srpnu roku 2011 došlo k oficiálnímu přejmenování na Psychologii náboženství a spirituality ${ }^{2}$. V roce 1997 vzniklo v New Yorku Centrum pro spiritualitu a psychoterapii v Národním institutu pro psychoterapii, které bylo v roce 2001 přejmenováno na Institut pro spiritualitu, vědu a psychoterapii ${ }^{3}$ a v současné době přepracovává vzdělávací koncepci pro 21. století. Centra pro spiritualitu, náboženství a zdraví (nebo Centra pro spiritualitu a zdraví) má i řada univerzit jako např́klad Dukeova, George Washingtona, univerzity v Minnesotě, Marylandu, na Floridě a další. Psychologie je prvním z oborů, v nichž spiritualita nalézá své vyjádření a této skutečnosti odpovídá i fakt, že prvními, kteří obnovili diskurs o spiritualitě na akademické půdě a vypracovali modely integrace psychologie a spirituality, byli W. James, Carl Gustav Jung a Roberto Assagioli. Psychodiagnostika spirituality je v současné době poměrně různorodá, napřr. MacDonald (2000) referuje o 70ti metodikách měřících tento konstrukt. Protože jde o poměrně exkluzivní dotazníky anebo škály, porovnávání dosažených výsledků bývá poměrně složité. V Čechách se psychometrií spirituality zabývá psycholog Pavel Říčan. S kolegyní Pavlínou Janošovou vytvořili v roce 2005 tzv. „Pražský dotazník spirituality“, který je obdobou amerických škál a jsou v něm tematizovány předpokládané projevy spirituality (Říčan 2007). V ostatních oborech (antropologii, sociologii, medicíně a dalších) se setkáváme zatím s izolovanými pracemi, ale jak už bylo naznačeno výše, velké oživení přichází $\mathrm{z}$ oblasti přírodních věd a systémových teorií. Zajímavé studie a výzkumy vycházejí z interdisciplinárního hnutí transpersonalismu, které přesáhlo hranice mateřské psychologické disciplíny a dnes zahrnuje transpersonální filosofii, psychiatrii, antropologii, sociologii a ekologii.

Fritjof Capra tvrdí (Capra 2004), že se dnes paradigma vědy posunulo od fyziky $\mathrm{k}$ vědám o životě, Josef Šmajs posouvá akcent na vědy o kultuře. Ve svých knihách důsledně upozorňuje, že kultura, kterou vytváříme, má kořistnický a protipřírodní charakter, a že lidská praxe by měla přijmout hledisko šetrného nájemního vztahu kultury $\mathrm{k}$ Zemi jako jedinému kosmickému domovu člověka. Zásadní otázku, kterou si pokládá, je: „Jak vytvářet kulturu dlouhodobě možnou?" (Šmajs 2008, 7). Podle Hany Babyrádové, je otázka vztahu člověka a kultury tím podstatným, co současného člověka zajímá v souvislosti s praxí jeho duchovního života. Duchovní obsahy se budou nacházet vždy ve specifické formě různých kulturních oblastí a v celém komplexu kulturního dění se budou navzájem prolínat a doplňovat. Také vzdělání a výchovu je nutno naplňovat duchovním poselstvím, protože nerespektování duchovního obsahu má za následek jednostranný pragmatismus, který zpětně oslabuje samotnou existenci kultury. „Kultura by totiž měla být žitá, a nikoliv pouze reflektovaná

2 srov. www.division36.org.

3 srov. http://psychospiritualtherapy.org/background.html $v$ intelektuálně koncipovaných komentárích. Průnik spirituality do kultury, ale i naopak kultury do spirituality, je možno nazvat inkulturací spirituality" (Babyrádová 2006, 25).

Komplexní studium spirituality $\mathrm{v}$ rámci kulturologického konceptu je jednou z možných cest $\mathrm{k}$ odpovědi. Při hledání nové syntézy ve vědách o člověku a kultuře došlo k vybudování nové disciplíny kulturologie. Kulturologie byla jedna z prvních věd, která svým interdisciplinárním pojetím aplikovala v praxi volání po konsilienci. Propojení přírodních a společenských věd vede $\mathrm{k}$ ideálu uceleného vzdělávání, které nám odkázala renesance a osvícenství. My jsme se mu ale během posledního století značně vzdálili (Wilson 1999). Pro řešení závažných problémů, které globální krize přináší je potřeba poznatky společenských a humanitních věd propojit se soudobými znalostmi, které nám poskytují prrírodní vědy. „Pouze plynulé prekračování hranic mezi vědami nám umožní nezkreslené vidění skutečného světa" (Wilson 1999, 18). Domnívám se, že spiritualita má v řešení těchto problémů své nezastupitelné místo.

Kulturologie je interdisciplinární obor a na rozdíl od jednotlivých společenských věd, které jsou úzce oborově zaměřené, se pokouší „odhalit vnitřní vztahy, které mezi jednotlivými dimenzemi kultury reálně existuji“" (Soukup 2011, 666). Vzhledem ke kulturologickému systémovému výzkumu sociokulturní reality, který vychází z předpokladu, že kulturu je možno zkoumat na třech základních strukturálních úrovních, můžeme kulturologickou koncepci použít i pro výzkum spirituality a kultury. Spiritualita jako předmět výzkumu je vnímaná duálně, jednak jako sám duchovní obsah a jednak jako spirituální proces, ve smyslu evoluce vyšších etap vědomí.

Spiritualita, zkoumá kulturu na úrovni

- $\quad$ rodu Homo: To co nás odlišuje od zvírat, tedy schopnost vůbec uchopit a nalézt spiritualitu u všech etnických a kulturních skupin.

Spiritualita studuje kulturní jevy na úrovni

- $\quad$ sociokulturních systémů: Spiritualita nabývá svých konkrétních forem a realizace $\mathrm{v}$ různých etnických a kulturních skupinách, to je ona pluralita a diverzita forem. Např́klad jako jeden z nástrojů pro dosahování mimořádných stavů vědomí, se v různých etnických skupinách používá tanec. Ale jiný je tanec dervišů a jiný je tanec křováků z Kalahari. Některé skupiny mají ve svém středu pro kontakt s jinými realitami svého zástupce - šamana, jiná společenství společně recitují mantry. Pluralita prožívání posvátna je široká, a dokud bude svět hlídat svoji diverzitu, bude uchovávat i svoje dědictví spirituálních cest a př́stupů.

Spiritualita studuje působení kultury na úrovni

- $\quad$ jednotlivce: Každý má v sobě vnitřní zdroj a stává se tvůrcem a produktem svého vlastního světa, své vlastní jedinečné spirituality a cesty, která stabilizuje život jedince ale také obětí patologické religiozity některých sekt, která je typická netolerancí, nenávistí a strachem. 
Jinými slovy, spiritualita při svém studiu kultury ukazuje, jak spiritualita vytvářela a vytvárí $v$ dějinách specifikum lidského rodu na úrovni živočišného rodu (pouze rod Homo je schopný ji vědomě proživat), na úrovni sociokulturních systémů, fenomén spirituality vytvárí svobodu multikulturní spirituality a na úrovni individua, kde se jedinci mohou stávat tvưrci svého vlastního světa, své jedinečné spirituality.

Obecná kulturologie, jako báze pro integraci poznatků a teorií dosažených na úrovni speciálních věd, vypracovala multidimenzionální explanační model, který se zabývá komplexním výzkumem kultury (Soukup 2011). Jak kulturologie, tak spiritualita má interdisciplinární charakter. Tento model proto může být použit pro komplexní studium spirituality. Tři základní strukturální úrovně v propojení s jednotlivými společenskými a prrírodními vědami, které spiritualitu z různých úhlů nazírají, budou především obsahem budoucí studie, ve které se ve schematickém náznaku pokusíme naznačit jednu z možných koncepcí studia spirituality v interdisciplinární syntéze.

Cílem předmětu studia "Spiritualita a kultura“ je navázat na tu část vědecké obce, která otevřela současný diskurs o spiritualitě na akademické půdě a najít širší platformu pro interdisciplinární studium spirituality. Spiritualita byla vytěsněna $\mathrm{z}$ vědeckého pohledu na svět a několik století se tísnila $\mathrm{v}$ podezřelých koutech. Tím, že neprobíhalo komplexní vědecké zkoumání této dimenze, má na sobě mnoho nánosů. Často je pojímána pouze jako alternativní spiritualita, a to vágně a úzce bez odpovídajících hlubokých znalostí západokřestanské vzdělanosti, východních filosofií a bez návaznosti na současné vědecké objevy.

\section{„ABY MĚL CAMERON CO ODPOVĚDĚT ANEB JAK Z KRIZE VEN“}

„Chceme-li zmènit systém s vnitřní informací (pamètí) musíme změnit jeho informaci“ (Šmajs 2000, 151). Zásadní problém pro kulturní, dnes protipř́rodní, vyprázdněný a člověku neprátelský systém nespočivá pouze $\mathrm{v}$ nalezení nového obsahu, který je v novém paradigmatu shodně rozpoznáván $\mathrm{v}$ duchovní oblasti, ale také $\mathrm{v}$ objevení cest a prostředků směřujících $\mathrm{k}$ tomu, „aby starý systém tuto informaci príijal“ (Šmajs 2000, 152). Pro pozitivní ekologickou proměnu kultury zdůrazňuje Josef Šmajs těsnou spolupráci filosofie, vědy a politiky. Vlajkovou lodí $\mathrm{v}$ tomto procesu by měla být akademická půda a na ní filosofové a vědci, kteř́ mohou $\mathrm{v}$ širokém kontextu objasnit probíhající změny. Na odborné úrovni mohou ovlivnit politiku a na všeobecně přijatelné úrovni poskytnout ontologické minimum pro širokou veřejnost, která může zpětně vytvořit tlak na politiku a změny v legislativě. $\mathrm{K}$ této horizontální, bezesporu důležité rovině, je ale nutné připojit i rovinu vertikální. Jak už bylo naznačeno výše je potřeba podpořit probíhající výzkum změněných stavů vědomí, uznat hodnotu a sílu vnitřní transformace a existenci vývojových stupňủ vědomí. Širokému proudu prudce se rozvíjejících a nově nastupujících „lidových“ a alternativních spiritualit je nutné poskytnout oporu v odborném a komplexním studiu spirituality. A nepopiratelně důležitou úlohou budoucí vědy se dnes jeví pokusit se rozkrýt hlubiny lidského vědomí a poskytnout lidstvu informace o dosud nevyužívaném potenciálu, kterým náš vlastní druh oplývá.

\section{LITERATURA}

Abraham, Ralph - McKenna, Terence - Sheldrake, Rupert (2008): Trialogy na hranicích Západu. Praha: DharmaGaia.

Babyrádová, Hana (2006): Původ a prítomnost fenoménu spirituality In: Babyrádová, Hana - Havlíček, Jiř́, eds., Spiritualita. Brno: Masarykova univerzita, 23-27.

Capra, Fritjof (2002): Bod obratu. Praha, DharmaGaia a Mata.

Capra, Fritjof (2003): Tao Fyziky. Paralely mezi moderní fyzikou a východni mystikou. Praha: DharmaGaia a Mata.

Capra, Fritjof (2004): Tkáň života. Nová syntéza mysli a hmoty. Praha: Academia.

Clegg, Brian (2009): Před velkým třeskem. Prehistorie našeho vesmíru. Praha: Dokořán.

Frecska, Ede (2010): Šamanská cesta: nadpřirozená, či přirozená? Neuroontologický výklad spirituálních zážitků. In: Strassman, Rick - Wojtowicz, Slawek - Luna Luis, Eduardo, Frecska, Ede, eds., Vnitřní cesty do vnějšího vesmíru. Praha: dybbuk, 185-232.

Hickman, Stephen (2010): Předmluva. In: Strassman, Rick - Wojtowicz, Slawek - Luna Luis, Eduardo, Frecska, Ede, eds., Vnitřní cesty do vnějšího vesmíru. Praha: dybbuk, 7-11.

Grof, Stanislav (1992a): Holotropní vědomí. Praha: Gemma89.

Grof, Stanislav (1992b): Teoretické a empirické základy transpersonální psychologie Přednáška z 12. mezinárodní transpersonální konference v Praze, konané 20. - 25. 6. In: Na vlnách změn. Praha: RADOST, 8-25.

Grof, Stanislav (1992c): Za hranice mozku. Praha: GEMMA89.

Grof, Stanislav - Grofová, Christina (1999): Krize duchovního vývoje. Praha: Chvojkovo nakladatelství.

Laughlin, Charles D. Jr. - McManus, John - Shearer, John (2011): Transpersonální antropologie. In: Walsch, Roger - Vaughanová, Frances, eds., Cesty přesažení ega: transpersonální vize. Praha: TRITON, 279-286.

Lovelock, James (2008): Gaia vrací úder. Praha: Academia.

MacDonald, Daniel, A. (2000): Spirituality: Description, measurement, and religion to the Five Factor Model of Personality. Journal of Personality, $68,153-197$

Metzner, Ralph (2011): Zelená psychologie. Praha: Triton.

Nešpor, Zdeněk - Lužný, Dušan (2007): Sociologie náboženství. Praha: Portál.

Ondok, Josef, P. (2001): Př́rodní vědy a teologie. Brno: CDK.

Otto, Rudolf (1998): Posvátno, Praha: Vyšehrad.

Pribram, Karl, H. (1999): Mozek a mysl. Praha: Gallery.

Pribram, Karl (1992): Mozek, mýtus: do 21. století. Přednáška z 12. mezinárodní transpersonální konference v Praze, konané 20. - 25. 6. In: Na vlnách změn. Praha: RADOST, 124-130.

Russell, Peter (2008): Od vědy k Bohu. Praha: dybbuk.

Russell, Peter (2011): Okno v čase. Praha: dybbuk.

Ř́ćcan, Pavel (2007): Psychologie náboženství a spirituality. Praha: Portál.

Sheldrake, Philip (2003): Spiritualita a historie. Brno: CDK.

Skolimowski, Henryk (2001): Účastná mysl. Praha: Mladá fronta.

Soukup, Václav (2011): Antropologie. Teorie člověka a kultury. Praha: Portál.

Šmajs, Josef (2000): Drama evoluce. Praha: Hynek.

Šmajs, Josef (2008): Potřebujeme filosofii přežití? Brno: nakladatelství Doplněk.

Štampach, Odilo, Ivan (2006): Nahradila spiritualita náboženství? In: Babyrádová, Hana - Havlíček, Jiří eds., Spiritualita. Brno: Masarykova univerzita, 99-109.

Štampach, Odilo, Ivan (1993): Život, duch a všechno. Duchovní směry nového věku. Brno: Sursum.

Teilhard de Chardin, Pierre (1990): Vesmír a lidstvo. Praha: Vyšehrad. 
Walsch, Roger - Vaughanová, Frances (2011): Úvod. In: Walsch, Roger - Vaughanová, Frances, eds., Cesty presažení ega: transpersonální vize. Praha: TRITON, 19-32.

Wilber, Ken (2010): Stručná historie všeho. Praha: Triton.

Wilson, Edvard, O. (1999): Konsilience. Praha: NLN.

Wilson, Edward, O. (1993): O lidské přirozenosti. Praha: NLN.

Zohar, Danah - Marshall, Ian (2003): Spirituální inteligence. Praha: Mladá fronta.

\section{INTERNETOVÉ ZDROJE}

www.diabasis.cz

www.division36.org.

http://psychospiritualtherapy.org/background.html

\section{AUTORKA}

Němečková, Kamila (19. 5. 1969), česká kulturoložka a právnička, doktorandka na Katedře teorie kultury (kulturologie) Filozofické fakulty Univerzity Karlovy v Praze. Po ukončení Právnické fakulty Univerzity Karlovy a před následným studiem na Katedře teorie kultury pobývala osm let v zahraničí, ve Francii (Toulouse), Švýcarsku (Ženeva) a Číně (Dalian). Zaměřuje se na interdisciplinární studium spirituality postavené na základech kvantové fyziky a dalších novodobých výzkumech. Ve svých přednáškách na katedře kulturologie představuje spiritualitu jako důležitou dimenzi lidské psychiky a univerzálního řádu věcí v kontextu vrcholící globální krize. Pozornost věnuje zejména novým teoriím poznání $\mathrm{v}$ jednotlivých vědách. Dlouhodobě se také zabývá individuačním procesem a snovou symbolikou.

Diplomová práce pod vedením Prof. PhDr. Pavla Ríčana: Spiritualita jógového hnutí v Čechách (2006), výsledky výzkumu odpřednášela na konferenci „Prožitek a hodnoty“ v roce 2008, (prezentováno ve sborníku z konference), připravovaná disertační práce: Proměna pojetí spirituality v postmoderní době.

Kontakt: Mgr. Kamila Němečková, Katedra teorie kultury (kulturologie) Filosofické fakulty Univerzity Karlovy v Praze, e-mail: kami. nem@seznam.cz. 